GSA Data Repository 2017027

Overbank sedimentation from the historic A.D. 2011 flood along the Lower Mississippi River, USA Heitmuller et al.

\title{
EXPANDED METHODS
}

Field sampling occurred in August and September 2011. A primary role of Dr. Richard Kesel (Co-PI of NSF-RAPID project) was to ensure that field-sampling procedures and study sites were consistent with that previously conducted during the 1973 flood investigation (i.e., Kesel et al., 1974). Most of the sites visited are correlative with a 1973 site, but others are at new locations and, in turn, some of the 1973 sites were inaccessible.

At each of the 49 sites visited, sediments deposited by the 2011 flood were closely inspected and identified by: (i) their relatively pale color indicative of low organic matter; (ii) occurrence on top of sheltered, undisturbed concrete pads or a distinct layer of vegetation litter; or (iii) for sands, position above a thin, relatively fine-grained recessional drape (Magilligan et al., 1998; Schalk et al., 1998; Shen et al., 2015) (see Figs. DR1-DR5 in the GSA Data Repository). Three representative measurements of thickness (mm) were made at each site, and the average was used for subsequent analysis and plotting. Additionally, GPS coordinates and flood-inundation depths (m), if preserved as silt or seed lines (Koenig et al., 2016), were recorded at each site. Further, a few sites exhibited evidence of overbank flow direction, such as dune or ripple crests or orientation of grasses pushed over by the flow, and a compass was used to measure their orientation. At 39 sites, a flood deposit sample was collected for laboratory analysis of organic matter content and particle size of inorganic sediments.

Sediment samples were characterized by Munsell color (moist sample) and analyzed for organic matter content (\%) and particle size (mm) in the USM Sedimentology Laboratory. Organic matter content (\%) was measured by heating a known dry mass of sediment to $550^{\circ} \mathrm{C}$ in a Thermo muffle furnace for $4 \mathrm{hr}$ and re-weighing the sediment sample. For particle-size analysis, $\mathrm{H}_{2} \mathrm{O}_{2}$ (30\%) was applied to a separate dry sample to remove organic material until no further reaction occurred. The remaining sediment was dried in a convection oven, disaggregated with a pestle and mortar, and $50 \mathrm{~g}$ of sediment was analyzed using hydrometer and wet-sieve procedures according to Gee and Bauder (1986). Pre-treatment procedures included standard physical and chemical disaggregation by milk-shake mixing and $5 \%\left(\mathrm{NaPO}_{3}\right)_{6}$.

Gee, G.W., and Bauder, J.W., 1986, Particle-size analysis, in Klute, A., ed., Methods of soil analysis: Part 1: Physical and mineralogical methods, $3^{\text {rd }}$ ed.: Madison, Wisconsin, Soil Science Society of America, p. 383-411. 
Kesel, R.H., Dunne, K.C., McDonald, R.C., Allison, K.R., and Spicer, B.E., 1974, Lateral erosion and overbank deposition on the Mississippi River in Louisiana caused by 1973 flooding: Geology, v. 2, p. 461-464.

Koenig, T.A., Bruce, J.L., O’Connor, J.E., McGee, B.D., Holmes, Jr., R.R., Hollins, R., Forbes, B.T., Kohn, M.S., Schellekens, M.F., Martin, Z.W., and Peppler, M.C., 2016, Identifying and preserving high-water mark data: U.S. Geological Survey Techniques and Methods, book 3, chap. A24, 47 p.

Magilligan, F.J., Phillips, J.D., James, L.A., and Gomez, B., 1998, Geomorphic and sedimentological controls on the effectiveness of an extreme flood: Journal of Geology, v. 106, p. 87-96.

Schalk, G.K., Holmes, Jr., R.R., and Johnson, G.P., 1998, Physical and chemical data on sediments deposited in the Missouri and Mississippi River flood plains during the July through August 1993 flood: U.S. Geological Survey Circular 1120-L, 62 p.

Shen, Z., Törnqvist, T.E., Mauz, B., Chamberlain, E.L., Nijhuis, A.G., and Sandoval, L., 2015, Episodic overbank deposition as a dominant mechanism of floodplain and delta-plain aggradation: Geology, v. 43, p. 875-878. 
Table DR1. Site-specific data of locations (WGS 84) and sedimentary characteristics for overbank flood deposits associated with the 2011 flood along the Lower Mississippi River near Fort Adams, MS, and St. Francisville, LA. Sediment thickness values for each site represent an average of three individual measurements sampled within a $\sim 20 \mathrm{~m}$ radius. Sites without sediment data indicate that only thickness was measured and samples were not taken. A thickness value of $0.0 \mathrm{~mm}$ indicates no 2011 flood deposits were able to be discerned. Thickness values for 1973 flood from Figure 1 of Kesel et al. (1974).

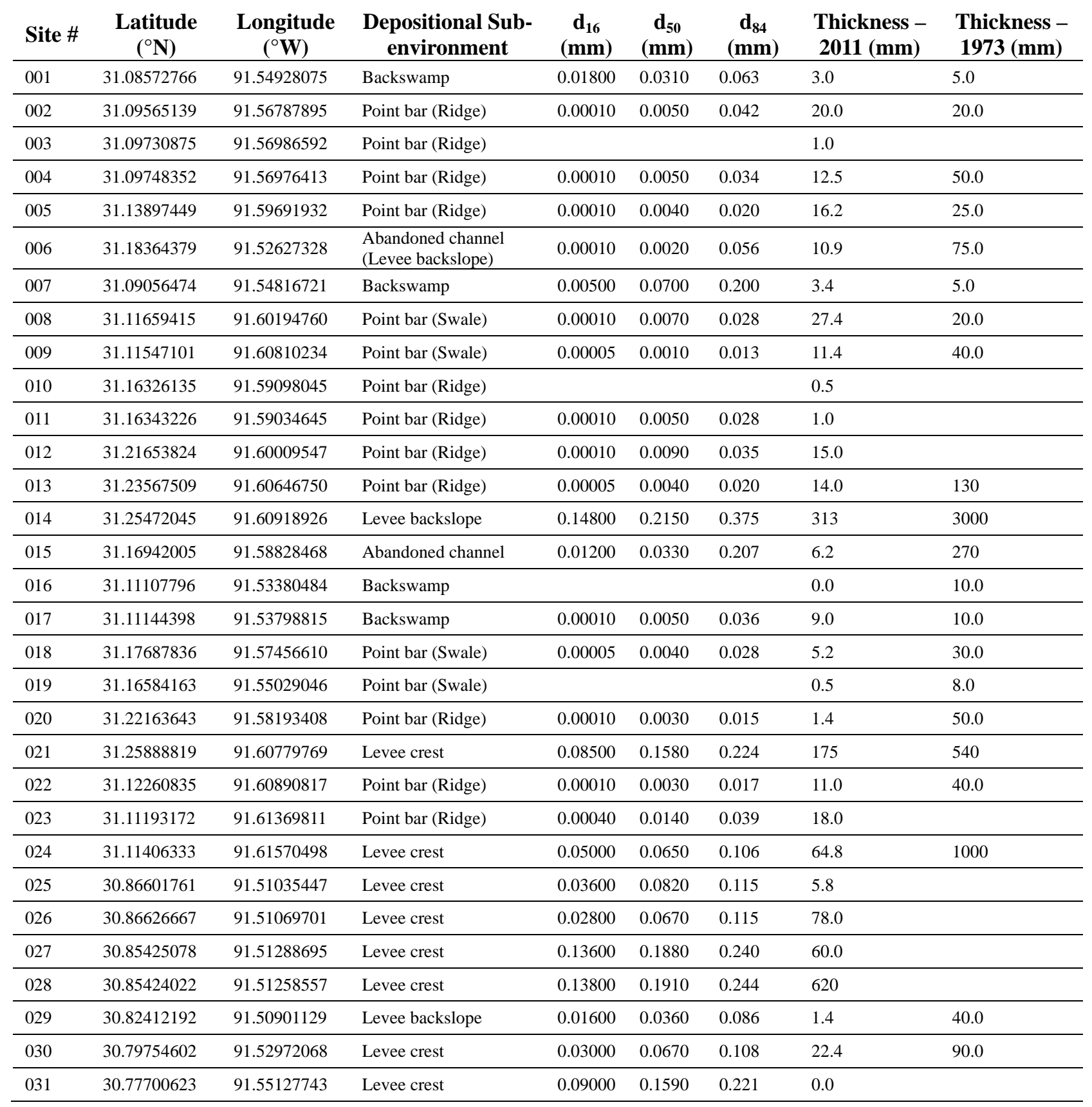




\begin{tabular}{|c|c|c|c|c|c|c|c|c|}
\hline 032 & 30.77831518 & 91.54803937 & Levee crest & 0.13700 & 0.2070 & 0.362 & 372 & 390 \\
\hline 033 & 30.78683069 & 91.45528033 & Backswamp & 0.00010 & 0.0010 & 0.009 & 2.6 & 25.0 \\
\hline 034 & 30.78450218 & 91.44959659 & Backswamp & & & & 2.6 & \\
\hline 035 & 30.76438254 & 91.47644199 & Point bar (Ridge) & 0.00010 & 0.0030 & 0.020 & 4.4 & 11.0 \\
\hline 036 & 30.76063152 & 91.47636185 & Point bar (Swale) & & & & 8.2 & 11.0 \\
\hline 037 & 30.75807545 & 91.49535452 & Point bar (Ridge) & 0.00005 & 0.0004 & 0.007 & 8.8 & \\
\hline 038 & 30.76050313 & 91.37126889 & Levee backslope & & & & 1.0 & \\
\hline 039 & 30.75976375 & 91.37221399 & Levee crest & 0.02000 & 0.0670 & 0.132 & 10.4 & \\
\hline 046 & 31.08655601 & 91.58093135 & Point bar (Swale) & 0.00010 & 0.0020 & 0.014 & 12.0 & 100 \\
\hline 047 & 31.08688217 & 91.58016038 & Point bar (Ridge) & 0.00005 & 0.0010 & 0.016 & 4.8 & 20.0 \\
\hline 048 & 31.09099612 & 91.58228547 & Point bar (Ridge) & & & & 5.4 & 20.0 \\
\hline 049 & 30.73788441 & 91.56435226 & Point bar (Ridge) & 0.03200 & 0.0800 & 0.114 & 4.0 & \\
\hline 050 & 30.73815152 & 91.56425633 & Point bar (Ridge) & 0.05100 & 0.0840 & 0.113 & 4.2 & \\
\hline 051 & 30.76068833 & 91.58852931 & Levee crest & 0.10500 & 0.1700 & 0.225 & 15.4 & \\
\hline 052 & 30.75770741 & 91.58373557 & Point bar (Swale) & 0.00010 & 0.0020 & 0.044 & 3.6 & 620 \\
\hline 053 & 30.75853418 & 91.58492129 & Point bar (Ridge) & & & & 3.0 & \\
\hline 054 & 30.77420754 & 91.56182314 & Levee crest & 0.09300 & 0.1650 & 0.225 & 89.0 & 460 \\
\hline 055 & 30.87476209 & 91.49834137 & Backswamp & & & & 0.0 & 10.0 \\
\hline
\end{tabular}




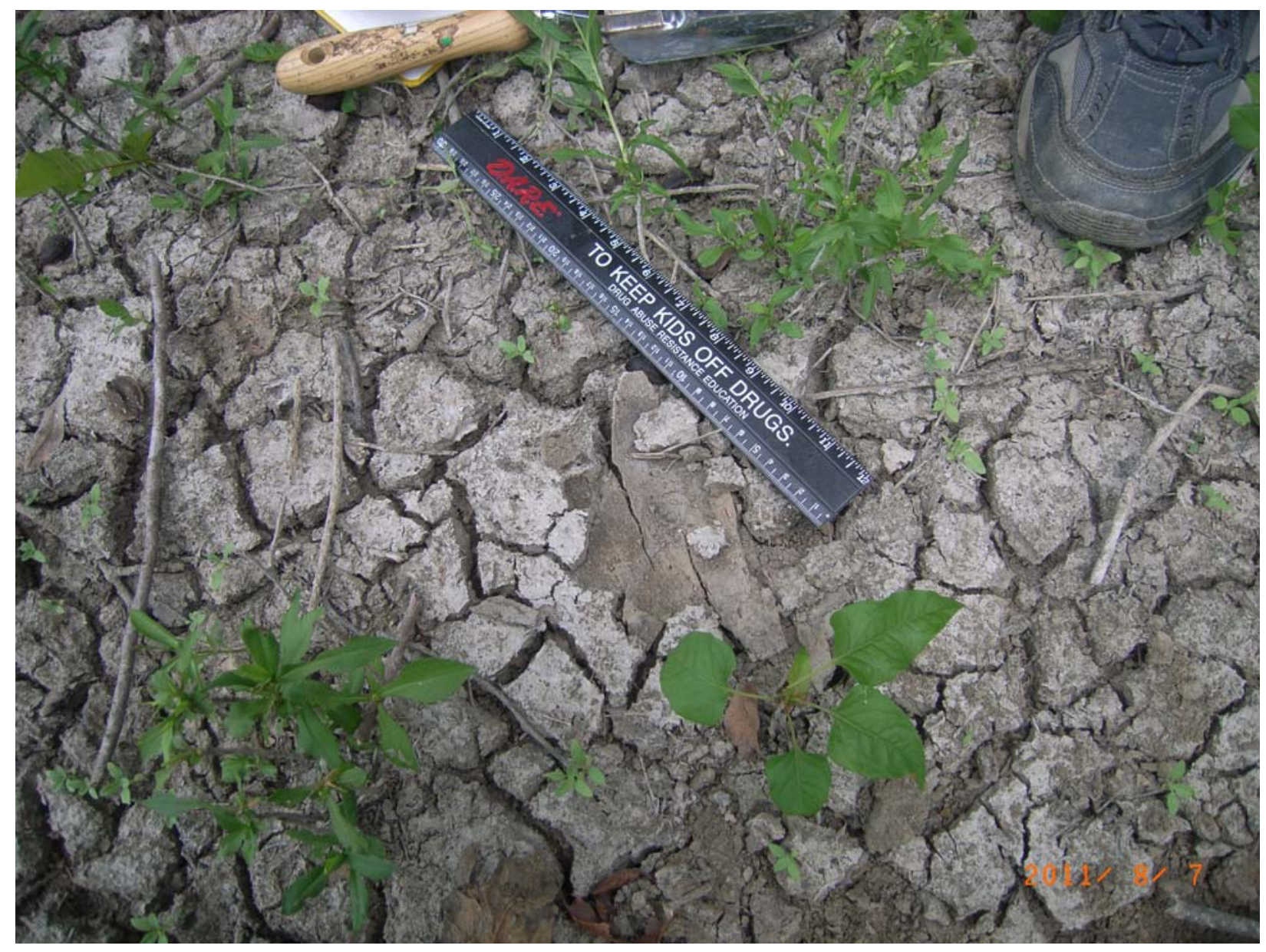

Figure DR1. Overbank sediments deposited by the 2011 flood along the Lower Mississippi River at Site \#004 near Fort Adams, Mississippi. Average thickness of the pale-colored, desiccated and cracked meander scroll ridge deposits was $12.5 \mathrm{~mm}$. 


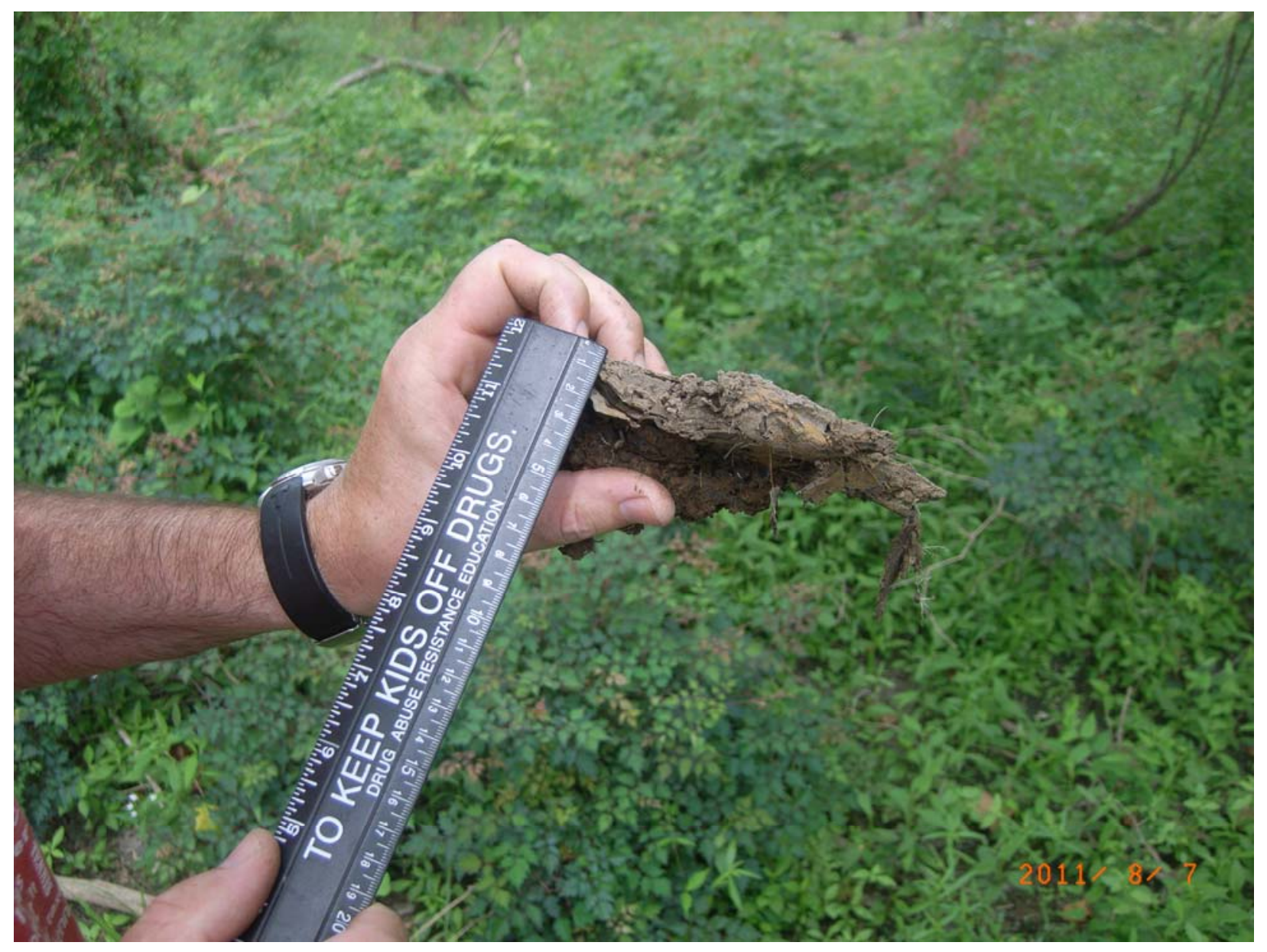

Figure DR2. Overbank sediments deposited by the 2011 flood along the Lower Mississippi River at Site \#002 near Ft. Adams, Mississippi. Average thickness of the relatively pale meander scroll ridge deposits was $20.0 \mathrm{~mm}$. 


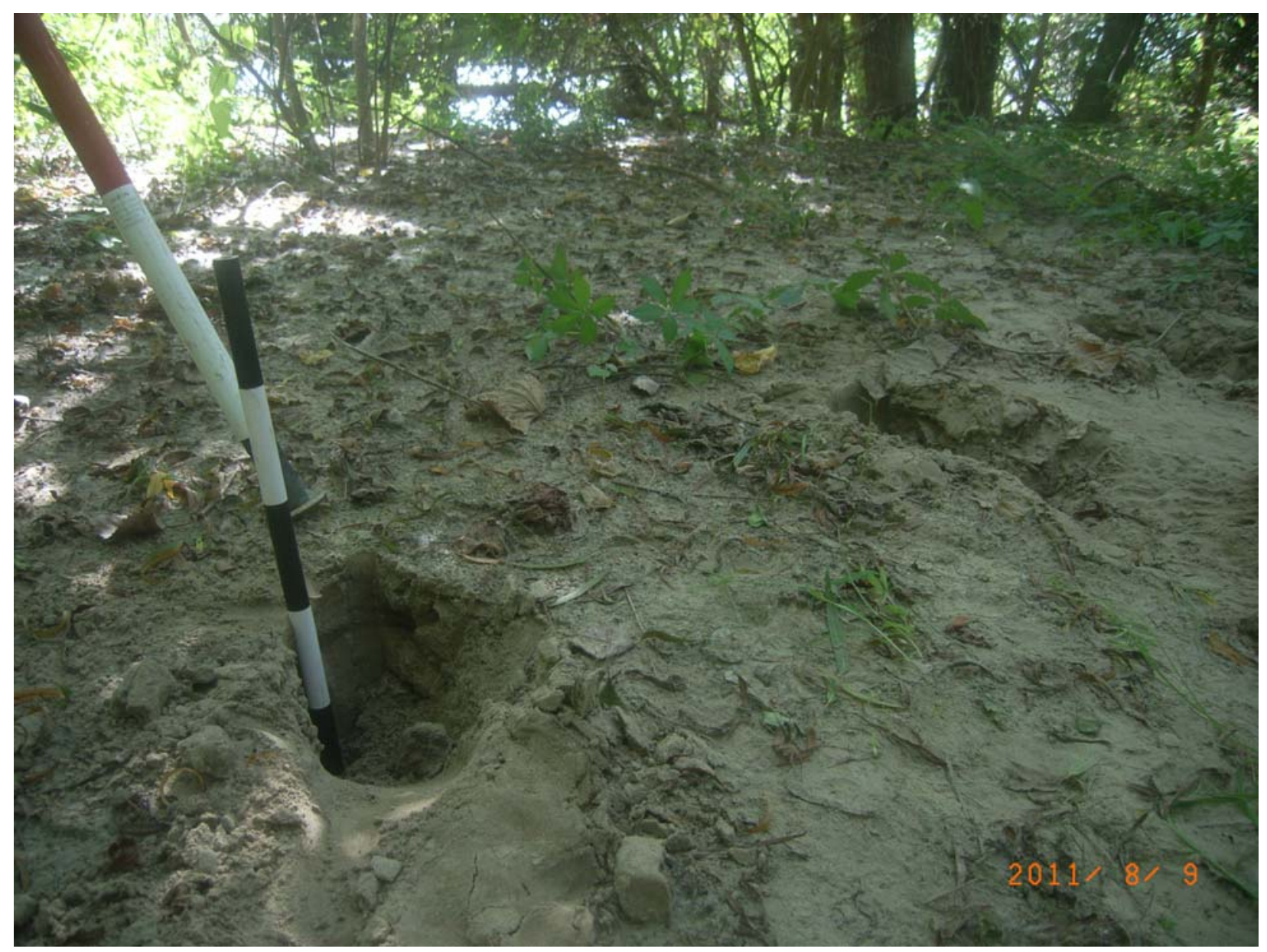

Figure DR3. Overbank sediments deposited by the 2011 flood along the Lower Mississippi River at Site \#024 near Artonish, Mississippi. Average thickness of the sandy natural levee deposits above the darker organic layer was $64.8 \mathrm{~mm}$. 


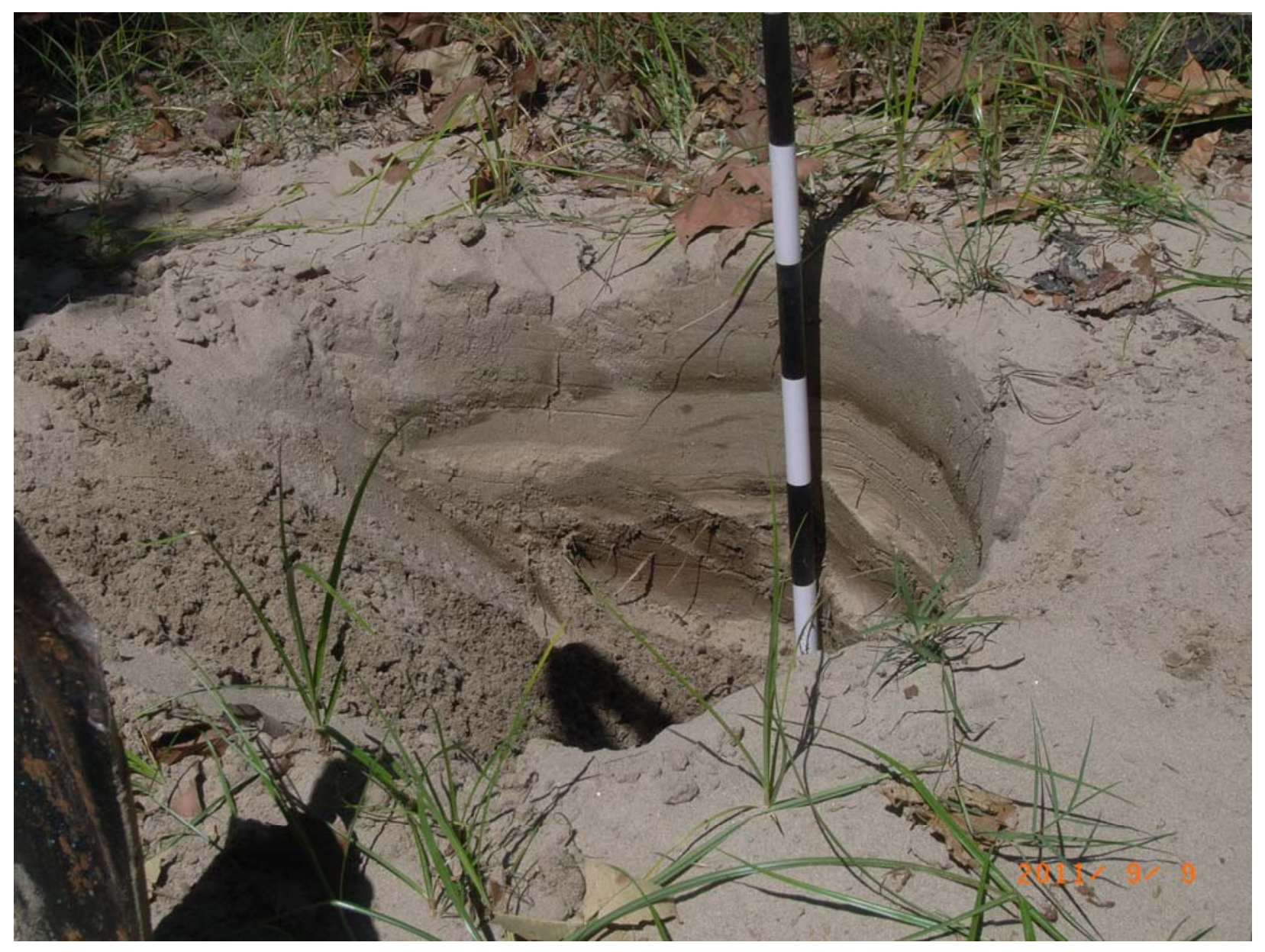

Figure DR4. Overbank sediments deposited by the 2011 flood along the Lower Mississippi River at Site \#054 near St. Francisville, Louisiana. Average thickness of the sandy natural levee deposits above the uppermost darker organic layer was $89.0 \mathrm{~mm}$. 


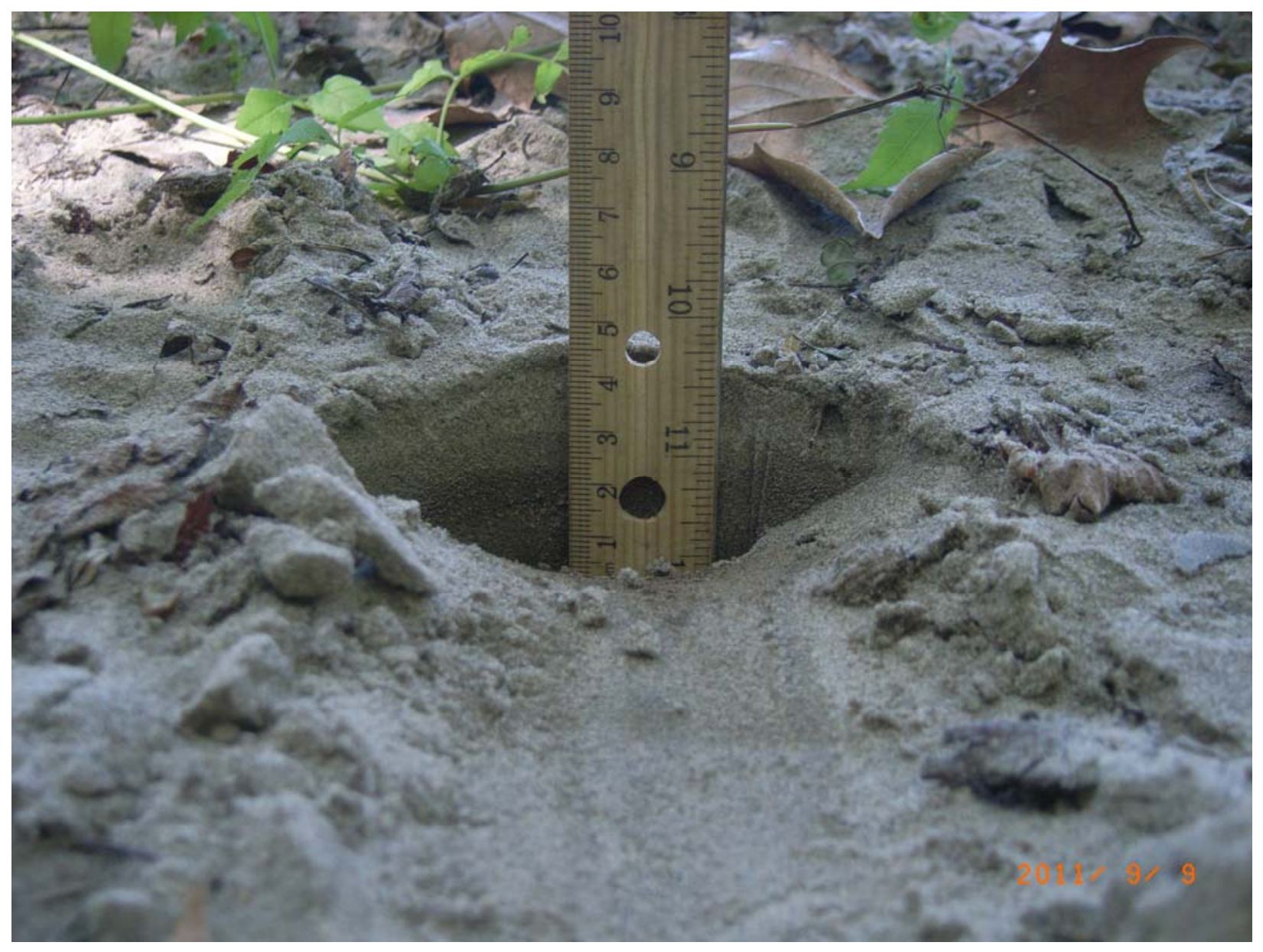

Figure DR5. Overbank sediments deposited by the 2011 flood along the Lower Mississippi River at Site \#051 near St. Francisville, Louisiana. Average thickness of the sandy natural levee deposits above the darker organic layer was $15.4 \mathrm{~mm}$. 

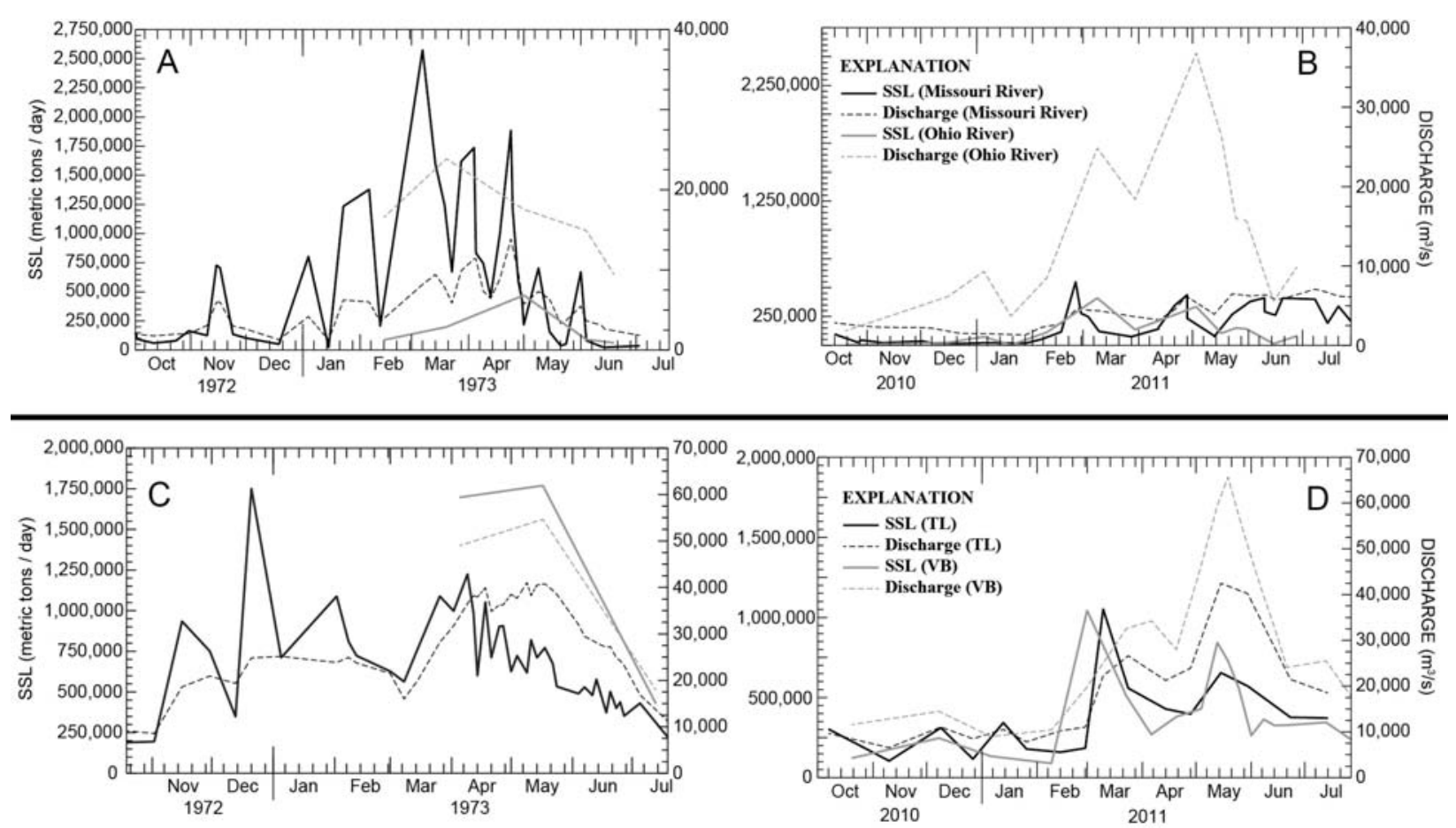

Figure DR6. Measured discharge and suspended-sediment loads (SSL) for the Missouri River at Hermann, MO (USGS 06934500) and the Ohio River at Dam 53 near Grand Chain, IL (USGS 03612500) (A and B), and the LMR at Vicksburg, MS (VB) (USGS 07289000) and Tarbert Landing, MS (TL) (USGS 07295100) (C and D) associated with the 1973 and 2011 floods (USGS, 2016). SSL values for USGS 06934500 are averaged for multiple measurements made during each day of data collection. 


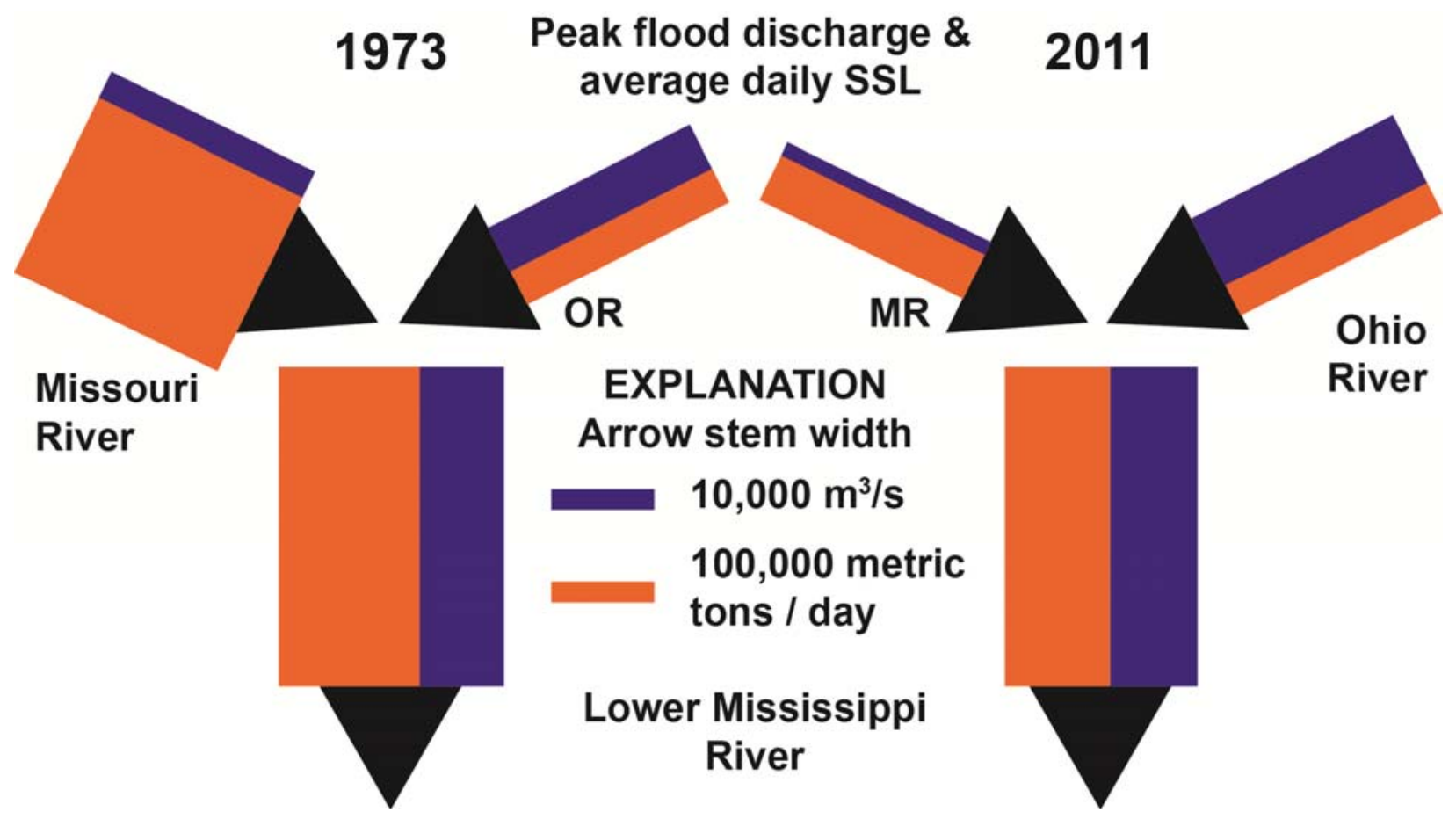

Figure DR7. Diagrammatic representations of peak discharges ( $\mathrm{m}^{3} / \mathrm{s}$ ) (blue arrow stems) and average daily suspended sediment loads (SSL) (metric tons / day) (orange arrow stems) of the Missouri (USGS 06934500), Ohio (USGS 03612500), and Lower Mississippi Rivers (LMR) (USGS 07295100) during the 1973 and 2011 floods along the LMR (USGS, 2016). Arrow stem color width is directly proportional to the peak discharge and average SSL transported during the contributing or flood hydrographs. Contributing hydrographs for the Missouri River (MR) are February $12^{\text {th }}$ to May $21^{\text {st }}, 1973$, and February $17^{\text {th }}-$ May $13^{\text {th }}$, 2011. Contributing hydrographs for the Ohio River (OR) are February $14^{\text {th }}-$ June $19^{\text {th }}$, 1973, and February $9^{\text {th }}-$ June $28^{\text {th }}, 2011$. Flood hydrographs for the LMR are March $8^{\text {th }}-$ July $5^{\text {th }}, 1973$, and February $28^{\text {th }}-$ July $14^{\text {th }}$, 2011. 